\title{
COVENANTS IN RESTRAINT OF TRADE: A SYNTHESIS OF TRADITIONAL, COMMON LAW AND CONSTITUTIONAL APPROACHES
}

\section{$1 \quad$ Introduction}

It seems as if cases dealing with covenants in restraint of trade will forever proliferate in the law reports. The reason for this phenomenon is simply that restraint clauses are by their very nature rather onerous contractual provisions in that they entail the curtailment of commercial activity and thus potentially hold grave consequences for the covenanter. Often the enforcement by the covenantee of such a contract is contested by the covenanter. When the enforcement of a restraint is sought two contractual values come into play: the principle of sanctity of contract (pacta sunt servanda) which holds the maintenance of agreements freely entered into, including limitations of future economic activity, as paramount, and the principle of freedom of trade which stresses the right of an individual to engage without restriction in economic activity. Although inter-related, there is an uneasy tension between these principles linked to the question of which of the two should be afforded preference in the circumstances (see generally Schoombee "Agreements in Restraint of Trade: The Appellate Division Confirms New Principles" 1985 THRHR 127 128-129). Other factors have further caused the South African law on restraint to be somewhat tumultuous, having been applied in terms of English and later Roman-Dutch law, and potentially influenced by the interim and final constitutions. Some recent provincial case law stresses the constitutional aspect of restraints while other decisions display a preference for the common law approach. The crisp question which this note seeks to address in light of the various forces which have been brought to bear on this area of the law of contract is whether at this stage a uniform resolution to the issue is apparent.

\section{$2 \quad$ Underlying values and ideology}

Somewhat ironically, both the principles of sanctity of contract and freedom of trade are derivates of the same broad ideology of market-individualism. As the name suggests, this ideology actually comprises two components; market theory and individualistic theory. Although mutually supportive in general, these two threads do entail fairly distinct concepts (see generally Adams and Brownsword Understanding Contract Law 4ed (2004) 189-194; Cockrell "Substance and Form in the South African Law of Contract" 1992 SALJ 40 41-42; and Pretorius "The Basis of Contractual Liability (1): Ideologies and Approaches" 2005 THRHR 253 258-261). 
Individualistic ideology focuses on the voluntary choices of parties to enter markets, choose their fellow contractors and conclude binding contracts on their own terms. This constitutes the broad notion of freedom of contract and incorporates the value of freedom of trade (see Adams and Brownsword 191-194; and Eiselen "Kontrakteervryheid, Kontraktuele Geregtigheid en die Ekonomiese Liberalisme" 1989 THRHR 516 517-519). Dominant ideas are those of individual autonomy and self-reliance (see Lubbe and Murray Farlam and Hathaway Contract: Cases, Materials and Commentary 3ed (1988) 20-21; and Cockrell 1992 SALJ 42). However, individual autonomy also implies responsibility for the consequences of decisions and, therefore, once the parties have concluded their contract they must abide by its terms and courts must require exact enforcement of the contract (pacta sunt servanda). This latter aspect is nothing other than the principle of sanctity of contract (Lubbe and Murray 21; and Adams and Brownsword 191). In terms of market theory the function of contract law is to facilitate competitive exchange by establishing the ground rules within which commerce can be conducted (see Atiyah The Rise and Fall of Freedom of Contract (1979) 402-404; and Hawthorne "The Principle of Equality in the Law of Contract" 1995 THRHR 157 164-165). A primary value emanating from the market ideal is a concern for the security of transactions, which coincidentally also affirms the notion that bargains freely entered into should be upheld by the courts (cf Adams and Brownsword 190; and Mulcahy and Tillotson Contract Law in Perspective 4ed (2004) 34-35).

Both these theories tend to support the principle of sanctity of contract, but covenants in restraint of trade further bring the principle of freedom of trade sharply into focus, requiring the curtailment of economic activity to be approached with a degree of caution. Academic commentary on the interplay between these two precepts varies between recognition of "a constant and real tension" between them (Schoombee 1985 THRHR 128 fn 7; and see similarly Van der Merwe, Van Huyssteen, Reinecke and Lubbe Contract: General Principles 3ed (2007) 213), to criticism of this perceived dichotomy on the basis that freedom of trade must include sanctity of contract because effective trade cannot occur if agreements are not honoured (Du Plessis and Davis "Restraint of Trade and Public Policy" 1984 SALJ 86 96; and see similarly Van der Merwe "Die Funksie van die Reëls ter Beskerming van die Handelsvryheid" 19882 TSAR 252 253).

Somewhat paradoxically, there seems to be a ring of truth to both accounts, but it should be borne in mind that although generally there is a complementary aspect to these principles (as do the two branches of market-individualism usually complement each other), there may be situations where tension between them arises and they tend to move into opposition rather than exist in unison. On an ideological level, this tension becomes apparent when the separate strands of market-individualism differ on the relative weight attached to a principle in specific circumstances. For instance, both individualistic and market theory observe that ideally contracts should be voluntarily incurred obligations (cf Cooke and Oughton The Common Law of Obligations 3ed (2000) 27). However, individualism holds individual autonomy and free will in primary esteem which culminates in a 
subjective approach to contractual liability (see Collins "Contract and Legal Theory" in Twining (ed) Legal Theory and Common Law (1986) 136142 144), whilst market theory affords greater priority to the security of market transactions and advocates an objective theory of consent (Adams and Brownsword 190). Within the context of restraints, therefore, it is entirely plausible that from an individualistic viewpoint individual autonomy generally favours freedom to engage in economic activity above the need to uphold agreements which limit that very principle. Conversely, from a market theory perspective the values of security and certainty dictate that by and large all contractual undertakings should be honoured, including those that curtail freedom of trade (cf Smith Atiyah's Introduction to the Law of Contract Ged (2005) 9-10 219). Therefore, within the context of the enforcement of restraint agreements it does seem as if freedom of trade and sanctity of contract are in a state of tension (cf Furmston (gen ed) The Law of Contract 2ed (2003) 951-952).

\section{$3 \quad$ Traditional approach}

The traditional restraint doctrine, which the courts favoured under the influence of English law, essentially was that covenants in restraint of trade were prima facie void and unenforceable, unless the covenantee could prove that the restraint was not contrary to public interest, and more specifically, reasonable as between the parties in that it served to protect specified interests of the covenantee. Once, however, reasonableness inter partes was established it was incumbent upon the covenanter to show that the restraint was nevertheless in conflict with public interest (see Van Heerden-Neethling Unlawful Competition 2ed (2008) 18; Schoombee 1985 THRHR 129-130; and Van der Merwe et al 214). This latter onus on the covenanter was not lightly discharged and it appears as if until 1984 no restraint was found to be invalid on the ground of public interest (Van Heerden-Neethling 18). A court would be prepared to sever the restraint and permit partial enforcement where it in fact comprised several distinct covenants (Joubert General Principles of the Law of Contract (1987) 146147; and Schoombee 1985 THRHR 131). The reasonableness of a restraint was determined with reference to the circumstances existing at the time of its conclusion and subsequent factors were irrelevant (Schoombee 1985 THRHR 131). The traditional approach thus appears to have been heavily weighted in favour of individual autonomy and freedom of trade at the expense of certainty and the principle of pacta sunt servanda (see generally regarding the traditional approach Kahn "The Rules Relating to Contracts in Restraint of Trade - Whence and Wither?" 1968 SALJ 391; Otto "Roffey v Catterall, Edwards \& Goudré (Pty) Ltd 19774 SA 494 (N)" 1978 THRHR 208; Du Plessis and Davis 1984 SALJ 91-96; and Joubert 144-150).

The main critique against the traditional approach was that it was out of step with the common law in that in Roman-Dutch law there was nothing to suggest that such agreements were prima facie void and unenforceable. The traditional doctrine had been adopted from English law seemingly without justification (see Katz v Efthimiou 19484 SA 603 (O) 610; Wessels The Law 
of Contract in South Africa Volume 1 2ed (1951) par 539; and Joubert 144145). English law appears to have generally had a pronounced influence on other legal systems in this regard (Otto 1978 THRHR 211) and although in its more modern form the law has become less rigid, the position is still that a restraint is void unless it serves to protect no far than is necessary the legitimate interest of the covenantee and is in the public interest. Traditionally, legitimate interests essentially comprised proprietary interests as personified in the goodwill of a business, and the trade connections and trade secrets of an employer (see generally on English law Furmston Cheshire, Fifoot and Furmston's Law of Contract 14ed (2001) 449-464; Treitel The Law of Contract 11ed (2003) 453-465; Beatson Anson's Law of Contract 28ed (2002) 366-376; Beale (gen ed) Chitty on Contracts Volume 1: General Principles 29ed (2004) 980-1008; Furmston 950-974; and Smith 219-227). Although a restraint which is reasonable inter partes may still be invalid if it is likely to prejudice the public interest, there is little direct authority in support thereof (Treitel 462; and Beatson 376). Nevertheless, with its strong emphasis on the reasonable protection of specified interests for the validation of a restraint, the question for present purposes is whether the pull of the discarded traditional doctrine is still evident in South African law (cf Schoombee 1985 THRHR 151).

\section{$4 \quad$ Common law approach}

In Magna Alloys and Research (SA) (Pty) Ltd v Ellis (1984 4 SA 874 (A)) the Appellate Division rejected the traditional approach and found that there was nothing in the common law which indicated that covenants in restraint of trade where invalid or unenforceable. Consequently, such a provision was entirely valid unless inimical to the public interest, in which event it would be unenforceable. The court found further as follows: it is in the public interest that agreements freely entered into should be enforced (sanctity of contract), but also that everyone should be free to engage in the commercial and professional world (freedom of trade); an unreasonable restraint would probably be contrary to public interest; the onus of proving that a restraint is contrary to the public interest rests on the covenanter; a court may have recourse to the circumstances existing at the time that enforcement is sought; and a restraint may be partially enforced if it is in the public interest (see the court's summary (897-898)). The common law approach, as formulated in this case, seems to have occasioned a complete reversal in the legal position regarding restraints and a concomitant preference for the principle of sanctity of contract above freedom of trade (for commentary on this case and related issues see Kerr "Restraint of Trade after Magna Alloys" in Visser (ed) Essays in Honour of Ellison Kahn (1989) 186; Otto "Inkorting van 'Restraint of Trade' - Bedinge in Kontrakte: Magna Alloys se Nageslag" 1997 THRHR 282; Visser "Magna Alloys and Research (SA) (Pty) Ltd v Ellis 19844 SA 874 (A)" 1985 De Jure 194; Pretorius "Covenants in Restraint of Trade: An Evaluation of the Positive Law" 1997 THRHR 6; Schoombee 1985 THRHR 134-151; Van Heerden-Neethling 18-20; and Van der Merwe et al 214-217). 
The main point of contention with the common law approach is that public interest is a fairly vague and amorphous notion and more concrete guidelines as to when a restraint should not be enforced were required. It was also uncertain to what extent reasonableness would still play a role since public interest was the touchstone for determining enforceability (see Schoombee 1985 THRHR 140-141; and Pretorius 1997 THRHR 8-9). It comes as no surprise then that the courts have on occasion been inclined to supplement the skeletal structure set in place by Magna Alloys (see eg Basson v Chilwan 19933 SA 742 (A) 767; and Kwik Copy (SA) (Pty) Ltd v Van Haarlem 19991 SA 472 (W) 484). More importantly, however, the judiciary proved to be more comfortable with the concept of reasonableness, closely associated with the traditional approach, and generally continued to apply this as the primary criterion in this regard (Reyburn Competition Law of South Africa (2000) (2005 update by Sutherland) 3-7; Van HeerdenNeethling 20; and cf Pretorius 1997 THRHR 8-13). The reasonableness of a restraint is determined primarily with reference to the protectable proprietary interest of the covenantee weighed qualitatively and quantitatively against the interest of the covenanter to be economically active and productive (Basson v Chilwan supra 767). Moreover, the activities affected, area and duration of a restraint must be of necessity be known to protect the threatened or infringed interest (Kwik Copy (SA) (Pty) Ltd $v$ Van Haarlem supra 484; see generally Van Heerden-Neethling 20-21; and Christie The Law of Contract in South Africa 5ed (2006) 362-363).

Consequently, while theoretically factors which have no bearing inter partes may have an effect on the enforcement of a restraint (see Van Rensburg, Lotz, Van Rijn, Christie and Sharrock "Contract" in Joubert, Faris and Harms (eds) LAWSA Vol 5 Part 1 2ed (2004) par 168; Van HeerdenNeethling 21-22; and Pretorius 1997 THRHR 9-16), the reasonableness of that restraint as between the parties still commands a pivotal role in this regard (dicta to this effect in case law are legion: see eg Automotive Tooling Systems (Pty) Ltd v Wilkens 20072 SA 271 (SCA) 277-278; Reeves v Marfield Insurance Brokers CC 19963 SA 766 (A) 776; CTP Ltd v Argus Holdings Ltd 19954 SA 774 (A) 784; and Basson v Chilwan supra 767). Aside then, from the question of onus, which will be addressed below, vital elements of the traditional approach have continued to carry weight in the application of the common law approach (see generally Van HeerdenNeethling 20-21; and of Van der Merwe et al 215-216). The common thread between the traditional and common law approaches becomes particularly evident when one considers whether there are indeed circumstances in which a restraint which is unreasonable inter partes nevertheless is not contrary to public policy (Schoombee 1985 THRHR 140). While conceivably the converse may apply in highly exceptional instances (cf Kleyenstrüber $V$ Barr 20013 SA 672 (W) 677-678; and Van der Merwe 19882 TSAR 206207), case law actually still very much revolves around the central issue of reasonableness as between the parties (see Kerr The Principles of the Law of Contract 6ed (2002) 215-216). 


\section{$5 \quad$ Constitutional approach}

With the advent of the constitutional age in South Africa, covenants in restraint of trade attracted renewed attention, the reason being that freedom to engage in economic activity was entrenched as a constitutional right initially in section 26 of the interim Constitution, 1993, and then section 22 of the Constitution of the Republic of South Africa, 1996 (see generally Rautenbach and Reinecke "Kontrakte ter Beperking van Handelsvryheid en die Grondwetlike Reg om Vrylik aan die Ekonomiese Verkeer Deel te Neem" 1995 TSAR 551; Grové "Waltons Stationery Co (Edms) Bpk v Fourie 19941 BCLR 50 (O)" 1994 De Jure 393; Woker "Restraint of Trade and the New Constitution" 1994 SA Merc LJ 329; Kerr 207-213; and Van der Merwe et al 213-214). This provided recalcitrant covenanters a ram with which to batter away at the common law position in relation to restraints. The courts, however, generally found the common law position not to be inconsistent with the constitutional dispensation (see eg Waltons Stationery Co (Edms) Bpk v Fourie 19944 SA 507 (O) 511; Kotzé \& Genis (Edms) Bpk v Potgieter 19953 SA 783 (C) 786-787; Knox D'Arcy Ltd v Shaw 19962 SA 651 (W) 661; CTP Ltd $v$ Independent Newspapers Holdings Ltd 19991 SA 452 (W) 468; Kwik Copy (SA) (Pty) Ltd v Van Haarlem 19991 SA 472 (W) 483; and De Klerk, Vermaak en Vennote v Coetzer 19994 SA 115 (W) 122).

Nonetheless, more recently, there have been a spate of decisions where, on the basis of section 22 of the Constitution, the courts have inclined in varying degrees toward a reversion of the onus to the covenantee (see eg Fidelity Guards Holdings (Pty) Ltd t/a Fidelity Guards v Pearmain 20012 SA 853 (SEC) 862; Lifeguards Africa (Pty) Ltd v Raubenheimer 20065 SA 364 (D) 376; cf Oasis Group Holdings (Pty) Ltd v Bray [2006] 4 All SA 183 (C) 193-195; see further Tait "Who Should Bear the Onus in Restraint of Trade Disputes?" 2004 Obiter 488; Du Plessis "Stare Decisis: Is the Onus in Restraints of Trade Hanging on a Thread?" 2006 TSAR 423; and Neethling "The Constitutional Impact on the Burden of Proof in Restraint of Trade Covenants - A Need for Exercising Restraint" 2008 SA Merc LJ 89). A more robust adaptation of the common law in regard to restraint of trade to conform to the constitution has also been advocated (see eg Coetzee $v$ Comitis 20011 SA 1254 (C), discussed by Nortjé "General Principles of Contract" 2001 Annual Survey 196 208-210; Canon KwaZulu-Natal (Pty) Ltd t/a Canon Office Automation v Booth 20053 SA 205 (N), discussed by Bhana and Nortjé "General Principles of Contract" 2005 Annual Survey 196 225-228; Advtech Resourcing (Pty) Ltd t/a Communicate Personnel Group v Kuhn 20082 SA 375; and Dickinson Holdings Group (Pty) Ltd v Du Plessis [2007] 1 All SA 583 (D)).

Isolated for present purposes and broadly stated, the constitutional approach focuses on the hegemony of section 22 (in effect freedom of trade) and generally observes that in consequence it is incumbent upon the covenantee to show (ie a reversion of onus) that in terms of section 36(1) of the Constitution, the restraint restricts the covenanter's right to choose his or her trade, occupation or profession freely (which includes the right to exercise or practice the chosen trade, occupation or profession freely: 
Affordable Medicines Trust $v$ Minister of Health 20063 SA 247 (CC) 274276; and Neethling 2008 SA Merc LJ 91) to the extent that the limitation is reasonable and justifiable in an open and democratic society based on human dignity, equality and freedom, and taking into account all relevant factors (see eg Coetzee v Comitis supra 1273; and Canon KwaZulu-Natal (Pty) Ltd t/a Canon Office Automation v Booth supra 209). A more general notion of whether the restraint in question is offensive to the aims and objectives of the Constitution has also been mentioned (see eg Dickinson Holdings Group (Pty) Ltd v Du Plessis supra 594), and reference has been made to section 39(2) of the Constitution, which provides that when developing the common law a court must promote the spirit, purport and objects of the Bill of Rights (see eg Canon KwaZulu-Natal (Pty) Ltd t/a Canon Office Automation v Booth supra 209; and Advtech Resourcing (Pty) Ltd t/a Communicate Personnel Group v Kuhn supra 385-388).

The rub with the constitutional approach lies in the fact that although the provincial courts are at times inclined to chip away at the common law standard with the constitutional broadsword, they are nevertheless constrained to have recourse to the more concrete tests for determining reasonableness that have been developed in case law when adjudicating upon the enforceability of a restraint. Shorn of constitutional technicalities, and irrespective of the question of onus, the enquiry inevitably revolves around the time-tested criterion of whether the restraint in question is necessary to protect a legally recognised, proprietary interest of the covenantee (see eg Canon KwaZulu-Natal (Pty) Ltd t/a Canon Office Automation v Booth supra 210-213; Dickinson Holdings Group (Pty) Ltd v Du Plessis supra 596-600; and see, however, Coetzee v Comitis supra 12701274 , where the offending provisions seem to have constituted multiple constitutional infringements). Practically speaking, therefore, the constitutional approach follows a pattern fairly similar to that of the traditional approach: a covenant in restraint of trade is invalid and unenforceable (for offending s 22 of the Constitution), unless shown to be reasonable in the circumstances (in accordance with the prescripts of s 36(1)). However, in actual fact, in the vast majority of cases reasonableness will hinge on whether the restraint is reasonable inter partes (cf Canon KwaZulu-Natal (Pty) Ltd t/a Canon Office Automation v Booth supra 209; and Grové 1994 De Jure 396).

\section{Reconciliation of approaches}

Recently, in Reddy v Siemens Telecommunications (Pty) Ltd (2007 2 SA 486 (SCA)), the Supreme Court of Appeal had occasion to reconsider the common law position in regard to restraint of trade covenants in light of the Constitution. In that case it was contended on behalf of the covenanter that the rule regarding the onus in such cases is in conflict with section 22 of the Constitution in that a restraint limits the right contained in this section, and is enforceable only if it is alleged and proved by the covenantee that the limitation is reasonable (495). On a general note, the court reaffirmed the importance of reasonableness inter partes (497) and further that the 
common law approach in balancing or reconciling concurring interests within this context gives effect to the precepts of the limitation clause (s 36(1)) of the Constitution (497-498) (see also recently eg Advtech Resourcing (Pty) Ltd t/a Communicate Personnel Group v Kuhn supra 389; and Canon KwaZulu-Natal (Pty) Ltd t/a Canon Office Automation v Booth supra 209). Perhaps even more tellingly it agreed with the sentiments of Rautenbach and Reinecke (1995 TSAR 558), although in regard to section 33(1) of the interim Constitution, that

"dit moeilik [is] om in te sien hoe daar bloot deur die feite deur 'n
konstitusionele bril te beoordeel, verbeter kan word aan die wyse waarop die
howe ingevolge die gemenereg die private en openbare belange teenoor
mekaar opweeg [" [ten opsigte van ooreenkomste ter beperking van
handelsvryheid] ..." (498).

Specifically as regards the question of who should bear the onus, the court stated that it was not called upon to decide this aspect but nevertheless concluded that where the onus lies in a particular case is a consequence of the substantive law on the issue. The substantive law as laid down in Magna Alloys is that a restraint is enforceable unless shown to be unreasonable, which necessarily casts an onus on the person who seeks to escape it. However, the court continued, even if the rule were to be reversed, the result in the present instance would have been the same because what was required was a value judgment, rather than a determination of what facts had been proved, and that the question of onus accordingly played no decisive role (495-496). What may be extrapolated from this reasoning is that in typical restraint cases, conducted by way of motion, proceedings where the facts are not in issue, the incidence of where the onus lies should have no material effect on the process of balancing private and public interests, and hence the outcome (cf Basson $v$ Chilwan supra 767; and Omni Technologies (Pty) Ltd t/a Gestetner Eastern Cape v Barnard [2008] 2 All SA 207 (SE) 211).

It is suggested that Reddy not only indicates that the common law position at present is entirely compatible with the Constitution, but further seems to show a preference for the manner in which the courts have balanced private and public interests in applying the common law. In essence then, the issue of the enforceability of agreements in restraint of trade is adequately dealt with under the common law and need not as a rule be adjudicated in constitutional terms (see also eg Automotive Tooling Systems (Pty) Ltd v Wilkens supra a recent Supreme Court of Appeal decision where no mention was made of the Constitution). In this vein this decision also implies a fairly cautious approach to the non-enforcement of a contract along constitutional lines (see Neethling 2008 SA Merc LJ 91; and cf Pretorius 1997 THRHR 2324), presumably with the purpose of preserving certainty and security in market relations freely entered into (compare more recently eg De Beer $v$ Keyser 20021 SA 827 (SCA) 837; Brisley v Drotsky 20024 SA 1 15-16 3536; Afrox Healthcare Bpk v Strydom 20026 SA 21 (SCA) 33-34; South African Forestry Co Ltd v York Timbers Ltd 20053 SA 323 (SCA) 338-339; and Napier v Barkhuizen 20064 SA 1 (SCA) 8). Moreover, as alluded to above, since the common law approach still relies heavily on the question of 
reasonableness inter partes, it seems as if the influence of the traditional approach will remain pivotal to the enquiry, notwithstanding recent dicta in provincial case law regarding the impact of the Constitution.

\section{$7 \quad$ Concluding observations}

It seems as if the law regarding covenants in restraint of trade has come full circle. The traditional approach, originally used and adopted from English law, favoured freedom of trade and regarded such undertakings as prima facie void and unenforceable, unless the covenantee could prove that the restraint was not contrary to public interest, and more specifically, reasonable as between the parties in that it served to protect specified interests of the covenantee. The common law, reinstated by Magna Alloys, emphasised sanctity of contract and regarded such covenants as entirely valid unless inimical to the public interest, in which event they would be unenforceable. Somewhat ironically though, public interest being a somewhat amorphous concept, the courts still primarily adjudicated these matters on the basis of reasonableness as between the parties. Although a restraint which is reasonable inter partes could still impinge upon an aspect of the public interest which has nothing to do with the parties, and a restraint which is unreasonable inter partes could nevertheless be found not to be contrary to public interest, the lack of direct case law exposes these instances as aberrations in the extreme. In actuality then, the traditional approach strongly influenced the manner in which courts set about resolving these matters in terms of the common law. The reason for this phenomenon seems to be that while there was nothing in the common law to suggest that restraints were per se inimical to public interest, there also was little in the way of actual indications as to when such agreements were contrary to public interest. In consequence, the courts sought comfort in that which they were familiar with, the traditional English doctrine, which had specific guidelines as to what constituted reasonableness and its polar opposite within this context.

With the advent of a constitutional dispensation which appeared to favour freedom of trade, another change in the law to some or other extent seemed imminent. However, the constitutional approach really amounted to a bald statement that a restraint was invalid for offending section 22 of the Constitution unless the limitation of this right was reasonable and justified in the circumstances (s 36). Once again, however, when actually determining what constituted a reasonable and justifiable limitation the courts were constrained to have recourse to the more concrete guidelines which by now were integral to the common law approach, but which essentially revolved around reasonableness inter partes, the nuclear test which had its genesis in the traditional doctrine. In Reddy the Supreme Court of Appeal showed convincingly that the common law approach actually adequately addresses the constitutional facets pertaining to restraint of trade and further implied that such instances call for a value judgment on the facts where the incidence of onus has little significance. 
The common law approach also seems to have the practical advantage over the constitutional approach in that it faces the issue head-on. Restraint disputes stem from contractual obligations, so on the one hand procedural and substantive issues peculiar to the law of contract which may arise in the circumstances will have to be addressed, and on the other hand the central question still remains whether a contractual undertaking should be enforced in the circumstances or not. The constitutional approach tends to focus on the entrenched right in question and then enquires as to whether the limitation of the right is reasonable and justified in the circumstances. The contractual matrix around which the entire dispute revolves is seemingly only obliquely relevant to the enquiry. However, once again, as to what is actually reasonable and justifiable in the circumstances can only really be determined with reference to the detail that has been fleshed-out by the courts in the past.

In concluding, it is suggested that despite the various forces that have influenced this facet of the law of contract since Magna Alloys, the pull of the traditional doctrine is still very much evident in the way in which restraint matters are adjudicated. On the other hand, aside perhaps from exceptional cases, Reddy portends that the constitutional approach will in all probability be subsumed under the common law approach, although some would probably argue that it is the other way round. Reddy also seems to suggest that generally in such matters the incidence of onus will not play a significant role since either way the central enquiry still revolves around the reasonableness of a restraint. On a broader level, this enquiry relates to the balancing of the values of freedom of trade and sanctity of contract in the specific circumstances. However, once the question of who bears the onus loses significance, a resolution between apparently disparate approaches becomes apparent: the common law approach is in line with the Constitution and actually gives concrete expression to the constitutional approach, while the former, although seemingly conceptually different, in practice applies the very same criterion of reasonableness inter partes that was integral to the traditional doctrine. It seems then that even in the modern constitutional age, the South African law on restraint still owes much to the English law, without which it certainly would have been the poorer. 